\title{
Philosophy and Post-Totalitarian Practices
}

\author{
Serhii Yosypenko
}

\author{
Doctor of Philosophical Sciences, \\ Head of the Department of the History of Ukrainian Philosophy \\ at H.S. Skovoroda Institute of Philosophy of the NAS of Ukraine, \\ Associate Professor of the Department of Philosophy and Religious Studies \\ at National University of Kyiv-Mohyla Academy. \\ E-mail: serhii.yosypenko@gmail.com \\ ORCID: 0000-0001-5928-6638
}

This writing aims to outline the principles of researches on philosophy in Central and Eastern European countries, preferably USSR, in the latest soviet and post-soviet periods. In author's opinion, the crucial points for such kind of research are: a) to discover a correlation between philosophy and the phenomenon of totalitarianism; b) to correlate a soviet philosophy with totalitarian experience. The article considers methodological and axiological problems in research of post-totalitarian practices in general as such as in philosophy. In author's opinion the main problem in development of the post-soviet philosophy is interiorisation of intellectual, cultural and social practices, which were formed concerning to totalitarian experience. This became a reason of "cynicism" and "nihilism" of post-soviet philosophy. It's impossible to cast mentioned phenomena off without consideration of totalitarian phenomenon and critical reconsideration of the own totalitarian experience.

Keywords: Central and Eastern Europe, totalitarian phenomenon, totalitarian experience, Soviet philosophy, post-totalitarian practices

Received: Fabuary 25, 2018; accepted: March 14, 2018

Future Human Image, Volume 9, 2018:

DOI: $10.29202 /$ fhi/9/14

\section{Introduction}

Philosophy is doubly connected with totalitarianism. One could be added "just as with any political regime", but there are probably two regimes with which philosophy has a special relationship. The emergence of philosophy is usually associated with the Athenian democracy, from which the modern liberal-democratic regime begins its genealogy.An incredible challenge for the philosophy of the twentieth century was a totalitarian regime. After the fall of Nazism appeared the question "how to philosophize after Auschwitz?" I do not support a thesis that

(C) Yosypenko, Serhii, 2018 
philosophy is possible only in one of the political regimes or that one of the regimes creates ideal conditions for philosophy or, conversely, that under any of the regimes philosophy is impossible at all. Since its origin, philosophy is possible always and everywhere, but each political regime creates for its philosophers its own conditions, which are a challenge for them, because these conditions must be objectified, that is, to realize the limits of the dependence and freedom of philosophical activity for a particular political regime, and also consider this political regime as a special case of linking philosophy with politics. Therefore, the question of the relation between philosophy and totalitarianism means, first of all, the question of the conditions of philosophizing under the totalitarian regime, and therefore of how these conditions affect the philosophy that arises in connection with a totalitarian project or in view of the totalitarian experience. And last but not least is the question of how philosophy can explain the totalitarian phenomenon, without which it is impossible to understand it as a condition of philosophizing and resist it and its consequences, including those ones that in this article will be called post-totalitarian practices. Under such terms, I will refer to political, intellectual, cultural, everyday and other practices that have arisen in totalitarianism and are maintained in the process of coming out of it, and which also significantly affect those formations and configurations that change the previous ones.

\section{Post-totalitarian practices and totalitarian phenomenon}

The transformation of post-totalitarian practices to the subject of research which is equivalent to totalitarianism, is often hindered by methodological and axiological, or even psychological reasons. Today, there are many convincing studies of the totalitarian phenomenon in where totalitarianism is almost always analyzed in the context of the establishment of liberal democracy. This creates an interesting transitological perspective: societies emerging from totalitarianism must, within the framework of the universal logic of the establishment of liberal democracy, return to it or build it. This perspective is quite consistent with the German situation, the feature of which should be streamlined. The Nazis gained a power in a democratic way, and although they immediately bigan to construct a totalitarian society, but for 12 years in power they did not have time to eliminate, completely change, and in some cases subordinate all institutions of the previous regime. This is the thing that distinguishes German totalitarianism from the Soviet one.

Instead, the exit from totalitarianism and the transition to liberal democracy in the West Germany has a completely different character. They are caused by military defeat, capitulation, occupation, the total elimination of Nazi institutions, the removal of political life, and often criminal punishment of those who involved in the previous regime, and so forth; at the same time, the occupation administration was the guarantor of the effectiveness and inevitability of democratic transformations. Another thing is the USSR and the countries of Central and Eastern Europe that were under its control. The totalitarian regimes are established here as a result of the military defeats of the previous regimes and / or Soviet occupation, the liquidation and the replacement of the institutions of the old regime show a revolutionary and often totalitarian nature. Communist authorities lasts for decades and undergoes a marked internal evolution which ultimately leads to the collapse of the Soviet system in democratic (as much as possible under the conditions of "developed socialism") way. In the transitological perspective, the countries of Central and Eastern Europe, after the collapse of communism, have to build liberal democracy (the way in which happened this collapse only exacerbates such expectations), 
and therefore everything that takes place here between totalitarianism and developed liberal democracy is evaluated only from the point of view of the lack or incompleteness of the last one or of remnants of totalitarianism. Therefore, the way out of communism must objectively be a longer and larger process and it becomesnon-subjective and uninteresting ${ }^{1}$ for research. Thus, in the opinion of the French sociologist - researcher of the communist and postcommunist Central and Eastern Europe, Georges Mink, "the situation after communism has, for many sociologists, an indistinct or even unpleasant taste. What is the disproportion between the brilliant collapse of the "cold monster" and the awesome effects of the postcommunist period! Was not this the result of so-expected collapse leading to revolutionary changes in social structures? ... However, nothing proves that there was a sharp change in societies, although according to sociologists' beliefs after 1989, social structures and mentality had to change as radically as the political and economic regime" [Mink, 2002: 443-444]. The contrast between expectations and reality was caused by the expectations. The expectations were greatly stimulated by the fact that the communist regime throughout its existence - up to 1989 in the case of the countries of Central and Eastern Europe and until 1991 — in the case of the USSR, was attributed the invariably totalitarian character. According to Krzysztof Pomian, a French philosopher and historian and former Polish communist and participant of the Polish dissident movement of the 1960s, "to assert totalitarianism of any regimes means to attribute it monolithic and exclude, as a result, the very possibility of changes caused by internal factors. Totalitarian regimes themselves are trying to create such an image for themselves, because accepting the existence of internal conflicts means for them to recognize the defeat of their project of building a united society" [Pomian, 1995: 20]. This perception not only makes the changes that took place in 1989-1991 more "brilliant" and the factors that caused them - less noticeable and, consequently, the consequences of these changes - more strange, it can lead to a reverse effect, because "equivalence of "totalitarian" and "monolithic" logically serves as an argument capable of making the very idea of totalitarianism. Each more or less in-depth study of the institutions of fascist Italy and Nazi Germany opens internal tensions and inconsistencies that contradict the image of the only unbreakable block" [Pomian, 1995: 20]. Outside the logic of the application of concepts and its effects there are axiological and psychological dimensions, in particular, not only representatives of the younger generation, but also people who grew up in the USSR, often tend to talk about the "horrors of totalitarianism" in the 1970s-80s, although this contradicts the elementary historical data and personal experience of those who lived in those years. A modern Polish scholar, Krzysztof Brzechczyn, aptly noticed that these epithets are more likely to mean the attitude to their own past and the desire to distance themselves from it: "the term "totalitarianism", which often appears in the titles of books or articles, is rarely a declaration of the author's theoretical beliefs (or editor of the collection), more often it serves as an axiological manifestation - a negative attitude to the social system designated by this term" [Brzechczyn, 2011: 69].

In a theoretical point of view, the definition of the Soviet regime as totalitarian is entirely correct in relation to the period preceding 1953-56, that is, the death of Stalin and the $20^{\text {th }}$ Congress of the CPSU, but needs to be clarified for the period 1953-56 - 1989-1991. In my opinion, there is not a very persuasive approach, according to which after 1953-56 there is a transition from totalitarianism to authoritarianism (or some other than totalitarianism of the

${ }^{1}$ The real research interest to a transitional state or transition problems can only cause fears (quite justified in the case of a number of post-Soviet countries) that post-totalitarian transformations can lead to some other political regime than liberal democracy. 
regime), and from 1989-91, from authoritarianism to democracy, since such the approach does not make it possible to understand the specifics of the "late Soviet regime." Considering it as a totalitarian one is a necessary, but insufficient condition for understanding this specificity, while the cornerstone is the question of the causes of the collapse of the Soviet system. If it was due to internal causes ${ }^{2}$, then its own evolution leads to collapse, and therefore we have different phases or stages of totalitarianism, at least until and after 1953-1956. (On the other hand, this evolution did not necessarily have to crash, and other scenarios similar to those realized in China, the DPRK or Cuba were possible). About such an evolution, says Pomian: "Was the Soviet regime totalitarian to the very end? Only one answer is possible here: it was a totalitarian regime that was heading towards its collapse. It was no longer practiced mass terror and there was no leader ... Due to this, the Soviet regime was no longer an emergency regime. He retained all the institutions of the totalitarian regime and the desire to build a society without a class struggle. But from now on, the bureaucratic routine replaces the will of the leader, and disappointment is the enthusiasm of the masses, even if he was artificial. The official comes to replace the ideological wrestler, money - to change the ideology, gerontocracy - to replace the cult of youth. Former fanatics turned into cynics" [Pomian, 1995: 22]. Although he believes that "the Soviet regime was transformed into an authoritarian regime which, in the same way, retained the Stalinist institutions and which could not appeal to the threat of a civil war for its legitimacy" [Pomian, 1995: 22], such Soviet "authoritarianism" was beyond mere the formal features of the exercise of power differed significantly from those that arose as a result of the degradation of the liberal-democratic regime. First of all, the aforementioned presence (and continuation of activity) of totalitarian institutions and the absence of civil society institutions, as well as post-totalitarian practices, carriers of which were Soviet people, engendered by a totalitarian experiment that markedly distinguished them from the citizens of yesterday's liberal democracies.

To clarify the specifics of the "late Soviet regime," I will use the criteria offered by Raymond Aron (1905-1983) in his work "Democracy and Totalitarianism" (1965), which was based on a course of lectures, read in Sorbonne in 1957-1958. This work differs from the well-known at the time of Aron's work "The Origins of Totalitarianism" (1951) by Hannah Arendt (19061975) in that Aron's reasoning was built on the comparison of the French Fourth Republic (1946-58), which was by no means the best example of liberal democracy, and the modern Soviet regime, that is, the USSR of the Stalin and Khrushchev period. This comparison takes place in the peculiar Aristotle's perspective of "the generation and corruption" of political regimes, reflection on the causes of their stability and instability, and also in the future of the formation of "industrial societies." Aron distinguishes five main principles of the "totalitarian phenomenon":

1. A totalitarian phenomenon arises out of a regime which gives a monopoly of political activity to one party;

2. The monopoly party is guided or armed with an ideology to which it gives absolute authority and which, as a result, becomes the official truth of the state;

3. In order to extend this official truth, the stateretains a dual monopoly - a monopoly of coercion and a monopoly of means of persuasion. The state and those who represent it fully manage and direct the totality of means of communication, radio, television and the press;

\footnotetext{
${ }^{2}$ Usually, contrary to this thesis, they indicate the subversion of Western countries with regard to the USSR, but during the Cold War the latter was doing the same thing against Western countries and losing this competition with them because of their internal weakness.
} 
4. Economic and professional activity is largely subordinated to the state and becomes, in some way, a part of the state itself. Since the state is inseparable from its ideology, economic and professional activities are largely marked by official truth;

5. Everything is state activity and any activity is subordinated to ideology, error committed in the economic or professional activity is both ideological error.Thus, the politicization and ideological coloring of all possible mistakes of individuals and, as a result, at the same time police and ideological terror . [Aron, 1965: 284-285]

All these principles remain valid until "perestroika", but does this mean that we have the only unchanging totalitarian phenomenon by the end of the 1980s? Changes that take place in the "late Soviet regime" can be noticed, above all, in paragraphs 4 and 5, although, of course, at the official level, the principles mentioned in them are preserved. To outline the difference between the two phases of totalitarianism, it is necessary to reconsider the peculiarities of the functioning of the "late Soviet regime" of the two core elements of totalitarianism, "whose essence is terror and whose principle of action is the logicality of ideological thinking" [Arendt, 1958: 474]. "The Late Soviet Regime" is totalitarianism, which abandoned terror as a form of existence, that is, from terror for the sake of terror (which does not exclude the use of repression in order to maintain order), and proposed a kind of normalization of the lives of Soviet citizens both at the level of personal security and at the level of well-being. The normalization, of course, did not mean giving any real rights or real prosperity to the Soviet people - the day's stagnation is a time of great inequalities, in particular between the elite and ordinary citizens, between the inhabitants of the capitals and industrial centers and the "outback" and the countryside; this is the time of great "deficits" (that is, the inaccessibility or inaccessibility of a number of material wealth of most citizens), as well as the great discrepancy between the official rules of "socialist legality" and the real rules of functioning of society and real practices of Socialdisciplinirung. The state-and-party retains a monopoly not only on political activity, but also on the determination of material and spiritual needs of citizens, as well as the definition of what is legitimate and just, that is, how to interpret and apply "socialist legality". These inequalities, differences and restrictions look scandalous for liberal democracy people, because they mean no fundamental freedom and any guarantees, but for the Soviet people who survived the Stalinist era, war, occupation, post-war devastation, stability itself has already looked a significant improvement in life, and the conditions for a kind of agreement proposed by the state and party: "You follow the rules we have established — we do not touch you", have been great progress in the field of personal security compared to the Stalin period when loyalty to the regime, merit to the regime or involvement in it in no way guaranteed personal security. After the Stalinist terror and instability, the terms of this agreement were quite understandable and acceptable, therefore, the Soviet people of the "era of stagnation" were relatively happy, although this did not interfere with the fact that they were somewhat dissatisfied in their lives. However, the subject of such dissatisfaction was rarely the actual political regime, at least even the dissidents rarely questioned the official principles of the "socialist system", criticizing mainly those Soviet practices that violated these principles. On the other hand, terror and instability ensured the dynamics, without which the totalitarian regime is falling, so the symptomatic name "the era of stagnation" in the context of totalitarian logic indicates the degradation and timing of the regime.

Just as it would be wrong to call terror any unjustified, unjust or voluntaristic use of force, and the existence of an ideology by itself is not yet a sign of totalitarianism. We can agree with Arendt that "....all ideologies contain totalitarian elements, but these are fully developed 
only by totalitarian movements, and this creates the deceptive impression that only racism and communism are totalitarian in character. The truth is, rather, that the real nature of all ideologies was revealed only in the role that the ideology plays in the apparatus of totalitarian domination" [Arendt, 1958: 470]. Communist ideology remains the official truth of the Soviet state until its collapse, but the totalitarian nature of the Soviet regime is conditioned not so much by the content of the communist doctrine, but by the way in which it determined the policy of the USSR and the behavior of its citizens. The state-and-party guided in their activities by the communist doctrine, but identifying it only with the teachings of Marx, Engels and Lenin is the same mistake as to deduce the policy and repression of the Soviet regime from the Constitution of the USSR and the official rules of "socialist legality". The real "guide to action" during the Stalinist era was based on the interpretation of the classics' disciples, but the monopoly on him, as well as all other interpretations, had only the "great leader and teacher", who was a living embodiment of the communist doctrine. So, Stalin was the supreme authority in all these domains, from agriculture and military affairs to art, philosophy and linguistics. However, after Stalin's death, his heirs (primarily for reasons of their own security) did everything to prevent the "cult of personality" revived in the USSR, whichaffected the role of ideology for the "late Soviet regime". The state-and-party leadership was led by people who managed not only to survive, but also to make a career in the environment of Stalin, as they understood and, perhaps, even introjeretized the principle that brilliantly expressed Arendt: "The ideal subject of totalitarian rule is not the convinced Nazi or the convinced Communist, but people for whom the distinction between fact and fiction \{i.e., the reality of experience) and the distinction between true and false (i.e., the standards of thought) no longer exist" [Arendt, 1958: 474]. Because of this, for the leaders of the "late Soviet regime," the communist doctrine becomes "dogma" rather than "guide to action", but in this capacity, "dogma" continues to perform its organizing role: the study of works of "classics of Marxism-Leninism" was an obligatory element of education, but the state-and-party and the party retained a monopoly on the understanding of what is a communist doctrine, and therefore any - which attempts to interpret the works of classics independently were perceived as an attack on this monopoly and, thus, on the state itself. Instead, the show of recognition of the official ideology and the adoption of any, even absurd, but official ideological statement, was a sign of loyalty to the regime.

Both the policy of the USSR and any professional activity in it until its very end remained subject to official ideology, but since the Soviet leadership had to deal with real economic, technological, ultimately social problems, he had to resort to decisions that were effective in his reign, but either did not rely on communist doctrine, or even contradicted it. It is clear that in the situation of choosing between an ideologically correct and efficient decision the simplest was to declare an effective solution ideologically correct, and therefore either to correct the ideological dogma, or to resort to its complex sophistic explanations, which became even more complicated when it comes to the abolition or change of previously declared ideologically correct solutions. The space for such adjustments and explanations was not so great, which reduced the possibility of truly effective decisions and often led to decisions absurd, but within this space, the possibility of partial denationalization of professional activity in a number of realms, the creation of original ideologically neutral areas, where one could be guided by its own professional logic, provided, of course, maintaining the loyalty of the regime, that is, the recognition of the supremacy of the communist doctrine over these professional logic.

\footnotetext{
${ }^{3}$ If you use the popular expression in the Soviet times by Friedrich Engels.
} 


\section{Philosophy and totalitarian experience}

Within the limits of such space, in my opinion, there is the formation of post-totalitarian Soviet philosophy, but this thesis needs a lot of refinements, especially the term "Soviet philosophy". The use of this term resembles the above-described methods of using the term "totalitarianism", in particular, its understanding also depends on the attitude to what it denotes. Often, under Soviet philosophy, only "Marxism-Leninism" means consciously or unknowingly reproducing of the official Soviet position and bringing the Soviet philosophy closer to ideology or its ideological function as much as possible. The opposite approach under Soviet philosophy means only that which is not limited to ideology or ideological function, and therefore what can be called philosophy from the present viewpoint. Thus, in the first approach, ultimately, the existence in the USSR of a philosophy independent of ideology, or of any value defined in this way by Soviet philosophy, is denied, and thus the gap between Soviet and post-Soviet philosophy is emphasized. In the second approach - on the contrary, the decisive is the desire to emphasize continuity between them, and often this continuity is understood as an absolutely positive factor. Thus, the leading Soviet and today's Russian philosophers, Abdusalam Guseinov and Vladislav Lektorsky, state: "The examination of what has been produced by today's philosophy, both from the points of view of the contributing authors, the range of themes investigated, and the conceptual solutions proposed, bears strong witness to a firm desire to be part of a continuity in relation to the history of philosophy. The debates and the principal outcomes achieved by Russian philosophy over the last twenty years fundamentally serve simply to extend, develop, enrich and bring to fruition the best of the intellectual endeavour of the years 1960 to 1980" [Guseinov, 2009: 20]. In my opinion, if it is true to analyze the philosophical literature of the post-Soviet period, then it is difficult to deny the continuity mentioned, but this approach causes a caveat . The remarkable selectivity of this approach is due to the traditional Marxo-Hegelian conception of history, as a linear process, aimed at fostering freedom and good, as a result of which the post-Soviet philosophy automatically turned out to be the heir of "the best of the intellectual endeavour of the years 1960 to 1980 ", and therefore, it automatically left in the USSR the worst thing that was done in these (and previous) years. This idea is well combined with the aforementioned transitological perspective, but this time at the end of the transition (which, according to the conviction of the authors, has already taken place), we have an ideal state for philosophizing: "At the beginning of the 1990s, and more particularly after August 1991, a situation became established that was new and generally favourable to the development of philosophy in Russia. The decisive contributing factor to this was the end of the monopoly of the Marxist vision of the world, or in other words the end of the centralised State control over ideology. Philosophy was able to become what it should always be, an unfettered intellectual endeavour, which contains within itself the determinants of its own truth and which constructs itself within the context of the academic community" [Guseinov, 2009: 18]. From such an opinion of the authors, one more problem arises from their approach — the totalitarian phenomenon and philosophy are taken in it as immutable, monolithic and always identical to the essence of itself, which is why the connection between them is conceived as purely external - one that can simply disappear if not for several days in August 1991, then, at least, in a few years of "perestroika". Moreover, without any special efforts on the part of the philosophers: "In Russia (contrary to other former Communist countries), the end of Marxism's monopoly has not led to the adoption of virulently anti-Marxist positions and has not been accompanied by professional interdictions. 
Remarkably, the evolution of theoretical stances within the philosophical community had not led to a wholesale change of personnel, apart of course from the natural processes of renewal and the surge of new recruits" [Guseinov, 2009: 18]. The author's description of the mechanism of transformation of Soviet philosophy in post-Soviet Russia is quite accurate, taking into account the peculiarities of the Russian case, but their optimistic assessment of this transformation has a reverse side: if this "evolution of theoretical stances" did not require any revision of the legacy of Soviet philosophy and had an exclusively cumulative character, then its connection with the totalitarian phenomenon was so insignificant that in all the reflections on "the best of the intellectual endeavour of the years 1960 to 1980 " can simply be made for brackets.

In order to identify such a connection and to find out its nature, in the study of Soviet philosophy one must bear in mind all the activities and products that were considered philosophical in the USSR, withing the conditions of philosophizing under the Soviet regime. It is clear that a significant part of these products had a purely ideological character, but ignoring the official philosophy or ideological component of Soviet philosophizing would mean ignoring not only its conditions, but also the very nature of post-totalitarian philosophy, that is, the philosophy that arises within the aforementioned denationalization or deideologization of educational, scientific, the cultural sphere for the "late Soviet regime" and continues its evolution after its collapse. The emergence in the USSR of post-totalitarian philosophy looks rather unusual phenomenon. With the advent of Soviet power, previous educational institutions were eliminated or fundamentally changed, old personnel - exiled, released, destroyed, new ones were trained from the class-based principles of people in the system of party education. The repressions of the 1930s destroyed most of the convicted Marxists and intellectuals who had some kind of training and / or pre-revolutionary education. As a result, the philosophical faculties restored during the Second World War were mainly full of people whose of philosophical knowladge did not go beyond the section "Dialectical and Historical Materialism" of the "History of the All-Union Communist Party (Bolsheviks): Short Course." At the same time, at the time of the collapse of the USSR in 1991, when the first graduates of these philosophical faculties barely reached retirement age, we see a developed system of philosophical knowledge with numerous research areas, topics and concepts. The possibility of philosophy, which was not limited to ideological function, was created with the normalization of social life, but its appearance did not occur automatically with the termination of terror. The most important factor behind the emergence of post-totalitarian philosophy was that it was called "de-Stalinization": after 1956, Soviet philosophers began to oppose the odious ideological guideline on the philosophy of the thesis drawn from the works of Marx, Engels and Lenin, sometimes even frankly criticizing the deviation of Stalinism from the spirit and the letter of discipleship the classics of "Marxism-Leninism". On the other hand, in the field of philosophy, new research directions, problems, and branches are discovered, the need for which is justified by the logic of the development of philosophy as a science (Marxist-Leninist philosophy was considered to be the most scholar of all philosophies), which is not limited to ideology, but also various institutional, educational, ideological and cultural demands of Soviet society on these directions, problems and industry. After a period of confusion and flirting with the humanities and the "creative intelligentsia" party leadership has since mid1960 puts an end to this amateur philosophers and proceeds to "crackdown" but a full return back did not happen and most new trends, issues and sectors preserved. The experience of "deStalinization" and its completion with "organizational findings", and in some cases - even 
repressions against individuals, showed the philosophers the limits of their capabilities for the "late Soviet regime": philosophers can engage in scientific research, but only on condition of political loyalty. Scientific research, including in new directions, issues and industries, should not contradict the official ideological truths, and the philosophical activity must not attack the monopoly of the state-and-party to establish such truths. These conditions were fully in line with the logic of the normalization of the life of Soviet citizens described above, and gave the Soviet philosophers, besides the ability to engage in research, a rather high social status of ideological ministers of the state-and-party. The internalization of these conditions by the Soviet philosophers creates an illusion of the normal development of philosophy for the "late Soviet regime," the only (external and, eventually, temporary) obstacles which were the "monopoly of the Marxist vision of the world" and "the centralised State control over ideology."

\section{Conclusions}

To counter of this illusion and its consequences is the consideration of the Soviet philosophizing of the 1960s-1980s as a post-totalitarian practice, that is, the inclusion of such a consideration of totalitarian experience as a condition for philosophizing. Such an approach can make it clear not only external but also internal constraints of Soviet philosophy as a pragmatic and cognitive plan that they inherited from it and post-Soviet philosophy. According to Vasyl Lisovyi, Soviet philosophers of this period, "avoiding conflict with the official ideology, began to compromise, adapting to ideological prohibitions and trying to do something positive within the limits of possible" [Lisovyi, 2008: 511]. These "limits of the possible" are outlined not only forbidden, but also how to do it is allowed. Party and academic authorities looked ater keeping this rules and Soviet philosophers usually knew them well, as well as the price paid for their violation. This situation contributed to the spread of the "cynical reason", which, according to Anatoliy Yermolenko's definition, "fully understands the distance between ideology and social reality, but does not renounce ideology ... it can be argued that in the seventies philosophers, few believed in the authentic truth of the Marxist theory. However, the cynicism of the seventies - the beginning of the eighties was fruitful. It made possible to distance to the Marxist theory, which should have become the basis for a critical reflection. However, the critical reflection of Marxism in the Soviet times did not take place, which was the reason for the smooth transition of such cynicism into the postcommunist era" [Yermolenko, 2003: 138]. In my opinion, the dominance of cynical reason led to a profound deformation of the profession de foi of Soviet philosophers, which signals the above-mentioned illusion of the normal development of philosophy, the only obstacle which is supposedly established by the power of the border. Transposing all responsibility for limiting the development of philosophy to power, the Soviet philosophers withdrew from themselves any responsibility for their own philosophizing; By making their dissatisfaction with external restrictions, they adopted numerous of internal constraints, more precisely self-restraint and, even, "self-censorship - deformations of thinking and speech that were not a direct consequence of the requirements of external censorship ... self-censorship often surpassed the requirements of external censorship" [Lisovyi, 2008: 512]. The main self-restraints concerned understanding of the subject of philosophy and its tasks. It should be recalled that Marxist philosophy, in accordance with the famous $11^{\text {th }}$ "Theses On Feuerbach", was intended to change the world, and such an understanding of the purpose of philosophy remains an official 
truth throughout the existence of the Soviet regime. Under totalitarianism, the state-and-party has a monopoly on how the world should be valued and what changes it is subject to: it is the competence of ideology or official philosophy. The competence of those branches of philosophy, which was not limited to ideology or attempted to get rid of its dictate, remains purely scientific, far from the immediate reality of the question (in the 1970s and 80s also, the problems of culture) or sophistic explanations of the peculiarities of ideological decisions. Such a division of competencies was even suited to those Soviet philosophers who tried to develop alternative for Marxist or official philosophy projects. Having adopted this division, the Soviet philosophers refused to make political or social reality a subject of professional interest (although the Marxist arsenal offered enough tools for this). As a result, it proved incapable to object the totalitarian phenomenon as a condition for their own philosophizing, to make it the subject of their critical reflection and to confront such a way for it and its consequences even when no one has forbidden it. This implies the consequences for the postSoviet philosophical theory: the lack of critical reflection of its Soviet past contributes to the preservation of the narrowed and deformed nomenclature of philosophical knowledge and relevant research practices developed in the 1960-1980s, which often leads to "restoration" (if we use Yermolenko's expression [Yermolenko, 2003: 139]), "the best of the intellectual endeavour of the years 1960 to 1980" and impedes the emergence or full development of new trends, issues and industries. The discovery in the post-Soviet period of Western philosophy (in the case of philosophical Ukrainian studies - of Humanities of Ukrainian Diaspora) could not completely compensate for the limitations, because such a discovery took place in accordance with the rather selective and deformed image of Western thought that developed during Soviet times within the framework of the "critique of bourgeois philosophy" (in the case of philosophical Ukrainian studies, "critique of Ukrainian bourgeois nationalism").

Similar problems caused by the post-totalitarian origins of modern Ukrainian philosophy and they require a critical reflection, which necessarily includes both analysis and the assessment of our own immediate past. The theses formulated in this article, of course, need to be developed and refined and aimed only at outlining the most obvious directions and the general explanatory scheme for such a reflection, the most fruitful form of which, in my opinion, will be the study of post-totalitarian practices in the field of philosophy on the example of individual figures, communities, institutions, research areas, and so forth. In particular, the analyzes and evaluations I have proposed are largely based on my own research on philosophical Ukrainian studies of the Soviet period and its post-Soviet transformations, as well as through the study of the figure and intellectual heritage of Vasyl Lisovyi (1937-2012), one of the few Soviet philosophers in Ukraine, who dared openly resist the above-mentioned compromises of the Soviet period and in independent Ukraine to fight against consequences of Soviet nihilism in Ukrainian philosophy and humanitarianism. I would like to dedicate this article to his bright memory.

\section{References}

Arendt, Hannah. The Origins of Totalitarianism, 2nd edition. New York: World Publishing Co., Meridian Books, 1958.

Aron, Raymond. Démocratie et totalitarisme. Paris: Gallimard, 1965.

Brzechczyn, Krzysztof. Metodologiczny status koncepcji totalitaryzmu a modelowanie dynamiki systemu komunistycznego, in: Uwikłania historiografii. Między ideologizacja 
dziejów a obiektywizmem badawczym (Studia i materiały poznańskiego IPN, t. XVIII, Eds. T. Błaszczyk, K. Brzechczyn, D. Ciunajcis, M. Kierzkowski). Poznań: Instytut Pamięci Narodowej, 2011: 67-84.

Guseinov, Abdusalam A.; Lektorsky, Vladislav A. Philosophy in Russia: History and Present State, in: Diogenes, 222 \& 223, 2009: 3-23. DOI: 10.1177/0392192109343635

Lisovyi, Vasyl. Ukrainian Philosophical Thought at 60-80-th of 20 century., in: Rusyn, Myroslav, Ogorodnyk Ivan, Bondar, Stanyslav and other. History of Ukrainian Philosophy. Kiev: Publishing Centre "Kyiv University”, 2008: 507-533.

Mink, Georges. La société postcommuniste : théories et données sociologiques, in: L'Europe post-communiste, Ed. D. Colas. Paris: PUF, 2002: 443-534.

Pomian, Krzysztof. Totalitarisme, in: Vingtième Siècle. Revue d'histoire, n47, 1995 : 4-23. DOI: $10.3406 /$ xxs. 1995.3177

Yermolenko, Anatoliy. Latest Marxism - The Philosophy of Cynical Mind, in: Latest Soviet Marxism and Present (To the 70th Anniversary of Vadim Ivanov). PhilosophicalAnthropological Studies, 2003. Kyiv: Stilos, 2003: 131-141. 